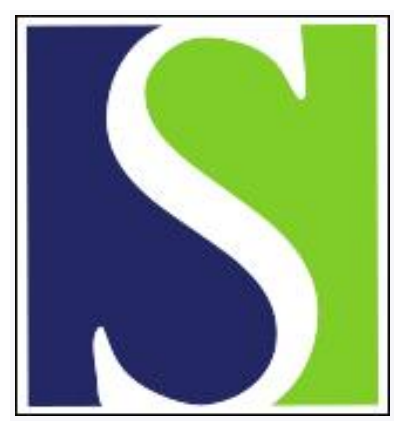

Scand J Work Environ Health 1977;3(2):100-103

https://doi.org/10.5271/sjweh.2789

Issue date: Jun 1977

Human urinary excretion of the herbicide 2-methyl-4-chloropheno xyacetic acid.

by Fjeldstad P, Wannag A

Key terms: 2-methyl-4-chloropheno xyacetic acid; 2-methyl-4-chlorophenoxyacetic acid; herbicide; high pressure liquid chomatography; human exposure; human urinary excretion; urinary excretion

This article in PubMed: www.ncbi.nlm.nih.gov/pubmed/882857

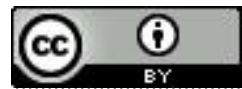




\title{
Human urinary excretion of the herbicide 2-methyl-4-chloropheno xyacetic acid
}

\author{
by PER FJELDSTAD and AXEL WANNAG ${ }^{1}$
}

\begin{abstract}
FJELDSTAD, P. and WANNAG, A. Human urinary excretion of the herbicide 2methyl-4-chlorophenoxyacetic acid. Scand. $j$. work environ. \& health 3 (1977) 100-103. To see if uxinary 2-methyil-4-chlorophenoxyacetic acid (MCPA) excretion could be used to estimate MCPA exposure, four healthy males ingested $5 \mathrm{mg}$ MCPA. The MCPA in the urine was extracted and analyzed by high pressure liquid chromatography. About $50 \%$ of the ingested dose was detected in the urine within $48 \mathrm{~h}$. On the fifith diay after intake the MCPA concentration in the urine was below the level of detection, $0.2 \mathrm{\mu g} / \mathrm{ml}$. The MCPA did not increase those serum enzymes indicating liver cell damage (S-alanine-aminotransferase, S-alkaline-phosphate). Some creatine kinase (CK) and S-aspartate-aminotransferase (ASAT) values were pathological, but, as all CK values were normal in two persons and all ASAT values were normal in three persons, it is not likely that MCPA had a toxic effect on muscle cells. MCPA in urine seems to be a useful indicator of MCPA intake in humans. All the urine passed within $48 \mathrm{~h}$ of MCPA exposure must be collected.
\end{abstract}

Key words: high pressure liquid chromatography, human exposure, 2-methyl-4chlorophenoxyacetic acid, urinary excretion.

Despite the extensive use of 2-methyl-4chlorophenoxyacetic acid (MCPA) in agriculture, there has been no study of the toxicity of MCPA in humans, and there is but limited knowledge of the toxicity of MCPA in animals.

The $\mathrm{LD}_{\tilde{0}, 0}$ in rats is around $800 \mathrm{mg} / \mathrm{kg}$ when MCPA is given orally and around $500 \mathrm{mg} / \mathrm{kg}$ when MCPA is injected intraperitoneally (8). In long-time exposure studies rats that received $50 \mathrm{ppm}$ MCPA in food for 90 days did not differ from control rats in growth, food intake, mortality, hematology, blood and liver chemistry, organ weights, or histopathology (10). However, $100 \mathrm{ppm}$ MCPA in the food for 7 months increased the relative kidney

1 Institute of Occupational Health, Oslo, Norway.

Reprint requests to: Mr. A. Wannag, Institute of Occupational Health, Gydas vei 8, Oslo-Dep., Osilo 1, Norway. weight of the rats, but had no effect on body weight, food consumption, mortality, hematology, or histopathology (8).

MCPA is absorbed from the gastrointestinal tract in rats $(5,10)$, rabbits $(10)$, mice (8), and cows (1), and it has been detected in the urine of cows (1) and rabbits (10). However, except for the study of Elo (5), no quantitative data are available either on absorption or on excretion. Elo found that male rats which received MCPA orally excreted nearly all of the MCPA during the first $24 \mathrm{~h}$ after intake (about $90 \%$ in urine and $7 \%$ in feces).

It can be expected that man will absorb MCPA through the skin, lungs and gastrointestinal tract. When the exposure of field sprayers to MCPA is evaluated, absorption through all these organs must be accounted for. Thus it would be preferable if the total amount of MCPA absorbed by the body could be measured. We undertook the present study in order to see if the urinary excretion of MCPA 
could be used as an indicator of MCPA absorption in humans.

\section{MATERIALS AND METHODS}

Four healthy males aged 32 to 36 years were given $5 \mathrm{mg}$ of MCPA orally. We recorded, but put no restrictions on, both physical activity and the intake of food, fluid and medicine.

\section{Urine}

A urine sample was obtained before the MCPA intake, and thereafter all urine was collected for the next 5 days. Ten days after the MCPA intake all urine was collected again for a 24-h period. The urine was collected and stored in polyethylene bottles and kept frozen $\left(-20^{\circ} \mathrm{C}\right)$ until analyzed.

The urine samples were hydrolyzed and extracted, followed by high pressure liquid chromatography (HPLC). The method is a modification of the one Erne (6) used for thin layer chromatography.

Ten-milliliter samples of urine were treated with $1 \mathrm{ml}$ of $5 \mathrm{M}$ sulfuric acid at $90-95^{\circ} \mathrm{C}$ for $1 \mathrm{~h}$ in a stoppered glass tube and then cooled at room temperature. The hydrolyzed samples were extracted three times with $1 \mathrm{ml}$ of chloroform. The water and chloroform were separated by centrifugation $(1,000 \mathrm{~g})$ for $5 \mathrm{~min}$. The total chloroform solution was extracted three times with $1 \mathrm{ml}$ of $0.25 \mathrm{M}$ phosphate buffer ( $\mathrm{pH}$ 6.2); acidification ( $\mathrm{pH} 2$ ) and extraction (3 times) into $1 \mathrm{ml}$ of chloroform followed. A small amount of anhydrous sodium sulfate was added to remove water from the chloroform solution. The volume was reduced to $250 \mu \mathrm{l}$ by nitrogen flushing at $50^{\circ} \mathrm{C}$.

HPLC was performed with a PerkinElmer LC 604 chromatograph equipped with a variable (LC 55) ultraviolet detector. MCPA was detected at $287 \mathrm{~nm}$. The MCPA peak was identified by its retention volume, and the peak height was measured. The purified samples were injected by means of a Valco loop injector fitted with a $30 \mu$ l loop. Separation took place on a column $(25 \times 0.3 \mathrm{~cm}$ i.d.) with Spherisorb Silica S5W (Spectra-physics) eluted with $\mathrm{v} / \mathrm{v}$ isooctane: chloroform (6:
1) containing $0.1 \%$ formic acid. The flow was $1 \mathrm{ml} / \mathrm{min}$, pressure $750 \mathrm{psi}$, and elution volume about $10 \mathrm{ml}$. The system was calibrated with samples of urine with MCPA added in various amounts. As a check on response and retention, a standard solution of MCPA in chloroform was injected between the samples. The coefficient of variation of the standards was $5.5 \%$. The detection limit of the method was $0.2 \mu \mathrm{g} / \mathrm{ml}$ urine. A background contribution of $0.1 \mu \mathrm{g} / \mathrm{ml}$ of urine was taken into account when the final standard deviation for every single analysis was estimated.

\section{Blood}

A blood sample (in a heparinized vacutainer) was taken before the MCPA intake and $2,7,12$ and $24 \mathrm{~h}$ after the intake. Further samples were taken 2, 3, 4 and 10 days after the intake. All the blood samples were immediately separated into plasma and erythrocytes. The plasma (in plastic tubes) was analyzed as soon as possible for S-aspartate-aminotransferase (ASAT), S-alanine-aminotransferase (ALAT), S-lactate-dehydrogenase (LD), S-alkaline-phosphate (AP) (2), creatine kinase (CK) (4), and $\gamma$-glutamyl transferase (GT) (3).

\section{RESULTS AND DISCUSSION}

The results are presented in table 1 and fig. 1. The main excretion of MCPA occurred within $48 \mathrm{~h}$ of intake. Up to then, about $2.5 \mathrm{mg}$ of MCPA had been passed in the urine. The fifth day after the MCPA intake, the concentration of MCPA in the urine was too small (less than 0.2 $\mu \mathrm{g} / \mathrm{ml}$ ) to be detected.

Because of the precision of the analysis, the differences observed in total MCPA excretion between persons after $48 \mathrm{~h}$ are not significant. Initially one person (fig. 1, no. 4) excreted less MCPA than the others, possibly because of individual differences in the rate of MCPA excretion in urine or because of differences in the rate of the gastrointestinal absorption of MCPA. However, the total amount of MCPA excreted in the urine was about 
Table 1. MCPA excretion in urine as the percentage of intake (5 $\mathrm{mg})$. The individual cumulative values of the four persons are given. The coefficients of variation are calculated on the basis of the estimated error of the amalysis.

\begin{tabular}{|c|c|c|c|c|}
\hline \multirow{2}{*}{ Person no. } & \multicolumn{4}{|c|}{ Houns after intake } \\
\hline & 24 & 48 & 72 & 96 \\
\hline 1 & $50.0 \pm 2.3$ & $56.6 \pm 4.4$ & $57.2 \pm 4.8$ & $57.2 \pm$ \\
\hline 2 & $42.9 \pm 1.4$ & $56.9 \pm 2.8$ & $59.0 \pm 3.5$ & $61.1 \pm 4.1$ \\
\hline 3 & $40.6 \pm 2.6$ & $47.7 \pm 6.5$ & $47.7 \pm 9.8$ & $50.0 \pm 10.1$ \\
\hline 4 & $29.3 \pm 2.4$ & $44.7 \pm 3.3$ & $50.9 \pm 4.4$ & $51.8 \pm 5.5$ \\
\hline Mean & 40.7 & 51.5 & 53.7 & 55.0 \\
\hline
\end{tabular}

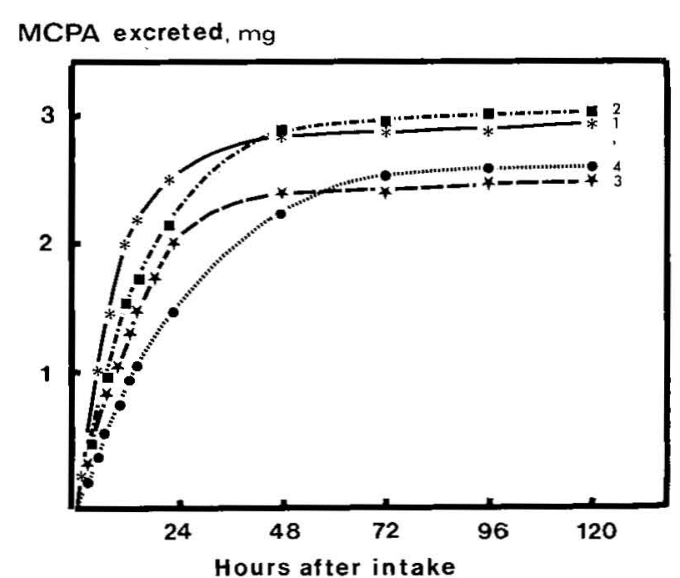

Fig. 1. MCPA excretion in urine after an oral intake of $5 \mathrm{mg}$ by four pensons, numbered $1-4$.

the same for all persons after $48 \mathrm{~h}$. Thus the urinary excretion of MCPA seems useful for estimating MCPA exposure when the total dose is about $5 \mathrm{mg}$. The estimation must be made from the amount of MCPA in all urine passed within the first $48 \mathrm{~h}$ of exposure.

Previous studies have shown that about $75 \%$ of 2,4-dichlorophenoxyacetic acid $(2,4-\mathrm{D})(9)$ and about $90 \%$ of $2,4,5$-trichlorophenoxyacetic acid $(2,4,5-\mathrm{T})(7)$ can be found in the urine of humans after oral intake. Our recovery of MCPA was less. However, these results may not reflect differences in the toxicokinetics of the compounds, but may be due to differences in the amount ingested. In the 2,4-D and 2,4,5-T studies $5 \mathrm{mg} / \mathrm{kg}$ of body weight were used; in our study the intake was $5 \mathrm{mg}$ per person. However, the possibility that MCPA undergoes biotransformation in humans cannot be excluded.

For only one person were all serum enzyme values within normal limits. Among the others, two had pathological enzyme values ( $\mathrm{CK}$ and $\mathrm{LDH}$ ) before the MCPA intake, and further abnormal values were detected during the days of observation. These pathological values were probably due to physical training, salicylate intake, and some hemolysis in the serum samples. ALAT and AP were normal in all four persons. Thus MCPA in the amount ingested does not seem to cause liver cell damage or intrahepatic cholestasis. Some CK and ASAT values were pathological, but a toxic effect of MCPA in muscle cells is not likely, as all $\mathrm{CK}$ values were normal in two persons and all ASAT values were normal in three persons.

\section{ACKNOWLEDGMENTS}

We wish to thank Dr. S. Skrede, who supervised the analyses of the serum enzymes at the Institute of Clinical Biochemistry, Rikshospitalet, Oslo, and K. E. Halgard at the Institute of Occupational Health, Oslo, for her skilled technical assistance.

\section{REFERENCES}

1. BACHE, C. A., LISK, D. J., WA.GNER, D. G. and WARNER, R. G. Elimination of 2-methyl-4-chlorophenoxyacetic acid and 
4-(2-methyl-4-chlorophenoxy) butyric acid in the urine from cows. J. dairy sci. 47 (1964) 93-95.

2. THE COMMITTEE ON ENZYMES OF THE SCANDINAVIAN SOCIETY FOR CLINICAL CHEMISTRY AND CLINICAI PHYSIOLOGY. Recommended methods for the determination of four enzymes in blood. Scand. j. clin. lab. invest. 33 (1974) 291306.

3. THE COMMITTEE ON ENZYMES OF THE SCANDINAVIAN SOCIETY FOR CLINICAL CHEMISTRY AND CLINICAL PHYSIOLOGY. Recommended method for the determination of $\gamma$-glutamyl transferase in blood. Scand. j. clin. lab. invest. 36 (1976) $1119-125$.

4. THE COMMITTEE ON ENZYMES OF THE SCANDINAVIAN SOCIETY FOR OLINICAL CHEMISTRY AND CLINICAL PHYSIOLOGY. Recommended method for the determination of creatine kinase in blood. Scand. j. clin. lab. invest. (in press).

5. ELO, $H$. Distribution and elimination of 2-methyl-4-chlorophenoxyacetic acid (MCPA) in male rats. Acta pharmacol. toxicol. 39 (1976) 58-64.

6. ERNE, K. Determination of phenoxyacetic herbicide residues in biorogical materials. Acta vet. scand. 7 (1966) $77-96$.

7. GEHRING, P. J., KRAMER, C. G., SCHWETZ, B. A., ROSE, J. Q. and ROWE, V. K. The fate of 2,4,5-trichlorophenoxyacetic acid $(2,4,5-\mathrm{T})$ following oral administration to man. Toxicol. appl. pharmacol. 26 (1973) 352-361.

8. GURD, M. R., HARMER, G. L. M. and LESSEL, B. Summary of toxicological darta: Acute toxicity and 7-month feeding studies with Mecoprop and MCPA. Food cosmet. toxicol. 3 (1965) 883-885.

9. KOHLI, J. D., KHANNA, R. N. and GUPTA, B. N. Absorption and excretion of 2,4-dichlorophenoxyacetic acid in man. Xenobiotica. 4 (1974) 97-100.

10. VERSCHUUREN, H. G., KROES, R. and DEN TONKELAAR, E. IM. Shont-term oraI and denmal toxicity of MCPA and MCPP. Toxicology 3 (1975) $349-359$.

Received for publication: 1977-11-12 